\title{
BDNF Increases the Number of Axotomized Rat Retinal Ganglion Cells Expressing GAP-43, L1, and TAG-1 mRNA-A Supportive Role for Nitric Oxide?
}

\author{
Nikolaj Klöcker, $*^{1,2}$ Marion J ung, ${ }^{+, 1}$ Claudia A. O. Stuermer, ${ }^{+}$ \\ and Mathias Bähr* \\ *Department of Neurology, University of Tübingen, 72076 Tübingen, Germany; and \\ ${ }^{\dagger}$ Department of Biology, University of Konstanz, 78457 Konstanz, Germany
}

\begin{abstract}
The death of neurons and the limited ability to activate growth-associated genes prevent the restoration of lesioned fiber tracts in the adult mammalian CNS. Here, we characterized the effects of the survival-promoting neurotrophin brain-derived neurotrophic factor (BDNF) on mRNA expression of GAP-43, L1, TAG-1, and SC-1 in axotomized and regenerating rat retinal ganglion cells (RGCs). BDNF led to de novo upregulation of TAG-1 mRNA in axotomized RGCs and to a threefold increase in the number of GAP-43 and L1 mRNA-expressing RGC s. SC-1 expression remained unchanged. However, BDNF did not improve long-distance axon regeneration into a peripheral nerve graft. Surprisingly, potentiating BDNF-mediated neuroprotection by simultaneous administration of a spin trap or a NOS inhibitor counteracted the BDNF-induced growth-associated gene expression. This led us to hypothesize that the BDNF effects on GAP-43, L1, and TAG-1 mRNA expression are mediated by a NOdependent mechanism. In summary, our data support the idea that survival and axon regeneration of lesioned CNS neurons can be regulated independently. 2001 Academic Press
\end{abstract}

\section{INTRODUCTION}

Neurons in the adult mammalian CNS show a very limited capacity of regenerating an axon after injury (Ramon y Cajal, 1928, 1991). This can be attributed to both extrinsic conditions and neuron intrinsic properties. The glial environment of lesioned CNS fiber tracts is growth inhibiting (Caroni and Schwab, 1988; Bovolenta et al., 1993; Schwab et al., 1993; McKerracher et al., 1994; Schachner, 1994; Hirsch and Bähr, 1999) and many neurons die in response to axotomy (Aguayo et al., 1991; Garcia-Valenzuela et al., 1994). Only some are capable of upregulating the expression of genes which are associated with axon growth during development

\footnotetext{
${ }^{1}$ The first two authors contributed equally to this study.

${ }^{2}$ Correspondence to: Dr. N. Klöcker, Dept. of Physiology, University of Tübingen, 72076 Tübingen, Germany. E-mail: nikolaj. kloecker@uni-tuebingen.de.
}

(Skene, 1989; Tetzlaff et al., 1991, 1994; Herdegen et al., 1997; Jung et al., 1997).

In the adult rat, $85 \%$ of the retinal ganglion cells (RGCs) die within 14 days after optic nerve $(\mathrm{ON})$ transection (Villegas-Perez et al., 1988, 1993). When offered a growth-permissive environment such as a peripheral nerve (PN) graft, $2-5 \%$ of the RGCs are able to regrow an axon into the transplant and to even functionally reconnect with their target area, the superior colliculus (David and Aguayo, 1985; Aguayo et al., 1991; Sauve et al., 1995). These axon-regenerating RGCs seem to represent a subpopulation of those RGCs that reexpress growth-associated proteins (Jung et al., 1997; Lang et al., 1998). Among them is growthassociated protein 43 (GAP-43) (Skene, 1989; Doster et al., 1991; Schaden et al., 1994). GAP-43 is expressed in RGCs normally only during embryonic and early postnatal development, when the visual projection is formed and refined (Reh et al., 1993; Kapfhammer et 
al., 1994), but it can be reinduced under lesion or outgrowth conditions (Doster et al., 1991; Meyer et al., 1994; Jo et al., 1999). Another growth-associated protein expressed by regenerating RGCs is the immunglobulin superfamily cell adhesion molecule (IgSFCAM) L1 (Jung et al., 1997), for which in vitro studies have proposed a role in intraretinal axon guidance during development (Brittis and Silver, 1995). However, other IgSF-CAMs such as TAG-1 and SC-1 are downregulated upon ON lesion (Jung et al., 1997). The loss of these (and others) might contribute to the low efficacy of RGC axon regeneration.

Brain-derived neurotrophic factor (BDNF) (Barde et al., 1982; Leibrock et al., 1989), a member of the neurotrophin gene family, is known to positively influence neuronal survival and differentiation during development (for review see Lindsay et al., 1994; Lewin and Barde, 1996). In the rat retina, BDNF promotes survival of postnatal and adult RGCs in various experimental lesion models both in vitro and in vivo (Johnson et al., 1986; Thanos et al., 1989; Mey and Thanos, 1993; Mansour-Robaey et al., 1994; Cui and Harvey, 1995; Meyer-Franke et al., 1995; Peinado Ramon et al., 1996) which is in good agreement with the finding that the vast majority of RGCs express the BDNF receptor TrkB (Jelsma et al., 1993; Barbacid, 1994; Rickman and Brecha, 1995; Cellerino and Kohler, 1997). We have recently shown that BDNF exerts not only neuroprotective effects, but also upregulates nitric oxide synthase (NOS) activity, thereby limiting its neuroprotective efficacy (Klöcker et al., 1998, 1999). Thus, simultaneous administration of the free radical scavenger $\mathrm{N}$-tert-butyl-(2-sulfophenyl)-nitrone (S-PBN) or the NOS inhibitor $N$ - $\omega$-nitro-l -arginine-methylester ( I-NAME) significantly increases BDNF-mediated cell rescue of axotomized rat RGCs.

In the present study, we investigated whether BDNF, alone or in combination with the free radical scavenger S-PBN, would affect the expression of the growth-associated genes GAP-43, L1, TAG-1, and SC-1 in axotomized and axon-regenerating RGCs. By this, we addressed the question whether the regulation of cell survival and the regulation of growthassociated genes and axon regeneration are mutually dependent or independent events.

\section{METHODS}

Animal surgery. Adult female Wistar rats (200-250 g; Charles River Wiga, Sulzfeld, Germany) were anesthetized by intraperitoneal injection of chloral hydrate
( $0.42 \mathrm{~g} / \mathrm{kg}$ body weight). The $\mathrm{ON}$ was transected as described before (Klöcker et al., 1998). Briefly, the orbita was opened saving the supraorbital vein and the lacrimal gland was subtotally resected. By means of a small retractor, the extraocular muscles were spread and the $\mathrm{ON}$ was exposed after longitudinal incision of the eye retractor muscle and the dura. The $\mathrm{ON}$ was transected 1-2 mm from the ocular bulb. To determine RGC densities, cells were retrogradely labeled with the fluorescent tracer Fast Blue (FB; Dr. Illing Chemie, Gross-Umstadt, Germany). To this end, a small piece of Gelfoam soaked in $2 \%$ aqueous FB was placed at the ocular stump of the $\mathrm{ON}$ after transection. For the autologous PN grafting procedure, the left common peroneal nerve was exposed, and a segment approximately $2 \mathrm{~cm}$ long was removed. The proximal end was apposed to the ocular stump of the transected $\mathrm{ON}$ and secured with three 10-O sutures at the adjacent sclera. The distal end of the graft was put on the dura of the temporal cortex through a hole drilled into the skull. For fluorescent labeling of regenerating RGCs, the PN graft was prelabeled with a small piece of gel foam soaked in 5\% 1,1'-dioctadecyl-3,3,3',3'-tetramethylindocarbocyanine perchlorate (DiI; Molecular Probes Inc., Eugene, OR) in dimethylformamide approximately $7 \mathrm{~mm}$ from the proximal end. Using this technique, we avoided a second axotomy of the regenerating RGCs and its effects on RGC survival and gene regulation. After surgery, preservation of the retinal blood supply was checked fundoscopically.

Drug administration. Recombinant human BDNF (Alomone Labs, Jerusalem, Israel) was dissolved in a $1 \%$ solution of bovine serum albumin (BSA) in PBS at a concentration of $250 \mathrm{ng} / \mu \mathrm{l}$. Under diethylether anesthesia, $2 \mu \mathrm{l}$ BDNF (500 ng) in BSA/PBS or $2 \mu \mathrm{l}$ BSA/PBS without BDNF (vehicle) were injected into the vitreous chamber of the eye by means of a glass microelectrode with a tip diameter of $30 \mu \mathrm{m}$ puncturing the eye at the cornea-sclera junction. BDNF/vehicle treatment consisted of either three intraocular injections on days 4,7 , and 10 after ON transection only or four intraocular injections on days 4, 8, 12, and 16 after ON transection and PN grafting. S-PBN (Sigma, Deisenhofen, Germany) was dissolved in PBS at a concentration of $100 \mathrm{mg} / \mathrm{ml}$. S-PBN treatment consisted of intraperitoneal injections of $1 \mathrm{ml} / \mathrm{kg}$ body weight every $12 \mathrm{~h}$ starting $30 \mathrm{~min}$ after surgery. INAME (Sigma) was dissolved in PBS at a concentration of $25 \mathrm{mg} / \mathrm{ml}$ (I-NAME 25). I-NAME treatment followed the same regimen as described for S-PBN.

Preparation of retinal whole mounts and quantification of axon-regenerating RGCs. Fourteen and 21 days after 
ON transection and 21 days after PN grafting, animals were killed by an overdose of chloral hydrate, and the eyes were removed and transferred to Hanks' buffered salt solution. The retinae were dissected, flatmounted on glass slides (for cell density determination), or attached by suction to a nylon filter (Hybond $\mathrm{N}+$, Amersham) with the photoreceptor layer down (for in situ hybridization). The basal lamina overlying the RGC layer was removed prior to fixing the retinae in $4 \%$ paraformaldehyde (PFA) in PBS for 20 min or overnight. For in situ hybridizations, the retinae were washed in PBS and incubated in 100\% methanol at $-20^{\circ} \mathrm{C}$ for at least $2 \mathrm{~h}$. To determine the cell densities, the retinae were examined under a fluorescence microscope (Zeiss Axiophot, Göttingen, Germany) equipped with the appropriate filter sets. DiI-labeled RGCs, i.e., RGCs which had regenerated an axon into the prelabeled PN graft, were counted in 12 distinct areas each of $62,500 \mu \mathrm{m}^{2}$ (three areas per retinal quadrant at three different retinal eccentricities of onesixth, one-half, and five-sixths of the retinal radius). Cell counts were done in duplicates and independently by two investigators.

Production of cRNA as hybridization probes and in situ hybridization. The following plasmids were used: pBKSII(-) containing a 1.6-kb insert of TAG-1 (kindly provided by A. J. W. Furley); pGEM-3 containing a 750-bp insert of GAP-43 (kindly provided by J. H. P. Skene); pBKSII(+) containing a 3.5-kb insert of SC-1 (kindly provided by T. M. Jessel); and pBKSII M 13 containing a 5.2-kb insert of NILE (kindly provided by W. Stallcup), the rat homolog of L1, and henceforth termed L1 (Bock et al., 1985; Prince et al., 1992). A total of $1.3 \mathrm{~kb}$ from the $5^{\prime}$ terminal region of L1 was subcloned in pBSKII(+) using the unique sites of BamHI/ $X h o I$. The plasmids were linearized with the appropriate restriction enzymes, treated with proteinase $\mathrm{K}$ (Boehringer Mannheim), extracted with phenol/chloroform, precipitated and labeled by in vitro transcription with a digoxigenin-(DIG) RNA labeling kit (Boehringer Mannheim) using T3, T7, or SP6 RNA polymerases. The riboprobe of SC- 1 was reduced to a mean size of $200 \mathrm{bp}$ by limited alkaline hydrolysis according to Wilkinson (1992).

In situ hybridization was carried out on retina whole mounts essentially as described elsewhere (Breitschopf et al., 1992; Westerfield, 1994; Jung et al., 1997). Retina whole mounts prepared as described above were divided into eight pie-shaped segments. Prior to in situ hybridization, the retinae were rehydrated at room temperature (RT), fixed with $4 \%$ PFA in PBS, treated with proteinase $\mathrm{K}(10 \mu \mathrm{g} / \mathrm{ml}, \mathrm{RT}, 10 \mathrm{~min})$. and fixed again in $4 \%$ PFA in PBS. The sections and whole mounts were then prehybridized at $55^{\circ} \mathrm{C}$ for $2 \mathrm{~h}$ prior to overnight hybridization (at $55^{\circ} \mathrm{C}$ ) in $500 \mu \mathrm{l}$ hybridization buffer ( $50 \%$ formamide, $2 \times$ SSCT, $10 \%$ dextran sulfate, and $1 \mathrm{mg} / \mathrm{ml} \mathrm{t}-\mathrm{RNA}$ ) containing the probe at concentrations ranging from 50 to $150 \mathrm{ng}$ per milliliter of hybridization buffer. The next day, the tissue was washed at $55^{\circ} \mathrm{C}$ in $50 \%$ formamide, $2 \times$ SSCT, and subsequently in $0.2 \times$ SSCT. After a blocking step (PBST, 2\% sheep serum (Sigma), 2\% goat serum (Vector Laboratories), $2 \mathrm{mg} / \mathrm{ml}$ bovine serum albumin (Sigma)), the tissue was incubated with anti-DIG-antibodies (1:2000 in PBST) for $2 \mathrm{~h}$ at RT and thoroughly washed in PBST prior to the signal detection with BM purple alkaline phosphatase (AP) substrate (Boehringer Mannheim). For double in situ hybridizations, the hybridization solution contained both a DIG- and a fluorescein-labeled riboprobe $(150 \mathrm{ng} / \mathrm{ml}$ each). First the DIG-labeled probe was detected using the antiDIG-AP developed with BM purple as described above. After washing steps in PBST the AP was inactivated by heat $\left(80^{\circ} \mathrm{C}, 20 \mathrm{~min}\right)$. The fluorescein-labeled riboprobe was then detected by incubation with an antibody against fluorescein-AP (1:2000), which was developed after washing steps in $0.1 \mathrm{M}$ Tris- $\mathrm{HCl} /$ $0.1 \%$ Tween with Fast Red (Boehringer Mannheim) according to the manufacturer's instructions. Whole mounts were embedded in Mowiol. All in situ hybridizations were made as doublets with the antisense and sense probes as control. Signals were found only with antisense probes. Labeled cells in retina whole mounts were counted in 40 distinct areas of $1 \mathrm{~mm}^{2}$ (10 areas per retinal quadrant at five different retinal eccentricities of one-sixth, two-sixths, three-sixths, four-sixths, and five-sixths of the retinal radius). Data were statistically analyzed using the Kolmogoroff-Smirnow test and are given as means \pm SD.

\section{RESULTS}

To determine whether BDNF and S-PBN influence the expression of growth-associated genes in axotomized and axon-regenerating rat RGCs, two sets of experiments were performed. In the first, BDNF was administered either alone or in combination with SPBN and the expression of GAP-43, L1, TAG-1, and SC-1 mRNAs was examined by in situ hybridization on retinal whole mounts. The mRNA-expressing RGCs were counted at 14 days after ON transection and compared with the survival rate of RGCs after the respective treatments (Klöcker et al., 1998). In the second set of experiments, mRNA-expressing RGCs were 
quantified 21 days after ON lesion and additional transplantation of a PN graft. This time point was chosen because it allows a subpopulation of RGCs to regenerate their axons into the graft and still assures retinal integrity after multiple injections of BDNF. These RGCs were identified by retrograde labeling using the fluorescent tracer DiI. In parallel, animals subjected to $\mathrm{ON}$ transection and BDNF treatment were analyzed 21 days after injury to serve as controls for the grafted rats.

\section{Effects of BDNF and S-PBN on the Number of mRNA-Expressing RGCS after ON Lesion}

BDNF leads to de novo synthesis of TAG-1 mRNA and increases the number of GAP-43- and L1-mRNA-expressing RGCs. Fourteen days after ON transection, a subpopulation of RGCs in untreated control retinae expressed the mRNAs of GAP-43 $\left(151 \pm 43\right.$ cells $\left./ \mathrm{mm}^{2}\right)$, of L1 $\left(415 \pm 78\right.$ cells $\left./ \mathrm{mm}^{2}\right)$, and of SC-1 $(25 \pm 25$ cells $\left./ \mathrm{mm}^{2}\right)$. TAG-1 mRNA, however, was not detected which is consistent with earlier findings (Jung et al., 1997) showing a decrease of TAG-1 mRNA below detection level in response to ON lesion (Figs. 1a-1d and 2a). Vehicle-injected controls did not show any significant difference in the number of RGCs expressing these mRNAs compared to untreated controls. Three intraocular injections of BDNF, however, led to an increase of TAG-1 mRNA expression in RGCs $\left(76 \pm 48\right.$ cells $\left./ \mathrm{mm}^{2}\right)$ resulting in a dense in situ hybridization signal throughout the RGCs somata. Moreover, there was an approximately threefold increase in the number of RGCs expressing GAP-43 mRNA $\left(539 \pm 129\right.$ cells $\left./ \mathrm{mm}^{2}\right)$ and L1 mRNA (1199 \pm 232 cells $\left./ \mathrm{mm}^{2}\right)$. No change in the number of SC-1 mRNA containing cells was observed (Figs. 1e-1h and 2a). Comparison of the RGC numbers expressing the respective mRNAs with the survival rates in untreated and BDNF-treated retinae demonstrates that all surviving RGCs express L1 mRNA independent of the treatment (Jung et al., 1997), but only $42 \%$ of the surviving RGCs without further treatment express GAP-43 mRNA (Table 1). This percentage is increased to $57 \%$ by intraocular BDNF injections.

The free radical scavenger $S$-PBN attenuates the effects of $B D N F$ on GAP-43, L1, and TAG-1 mRNA expression. Combined treatment with BDNF and S-PBN after ON lesion leads to a significant increase in cell survival compared with single BDNF treatment (Klöcker et al., 1998). However, the number of RGCs expressing mRNAs of GAP-43 $\left(289 \pm 119\right.$ cells $\left./ \mathrm{mm}^{2}\right), \mathrm{L} 1(890 \pm$ 177 cells $\left./ \mathrm{mm}^{2}\right)$, and TAG-1 $\left(50 \pm 22\right.$ cells $\left./ \mathrm{mm}^{2}\right)$ de- clined and fell even below the levels obtained with BDNF alone (Fig. 2a). The number of SC-1 mRNA expressing RGCs did not change under combined treatment with BDNF and S-PBN. Treatment with SPBN alone, while having no effect on RGC survival (Klöcker et al., 1998), led to a significant decrease in the number of GAP-43- $\left(68 \pm 7\right.$ cells $\left./ \mathrm{mm}^{2} ; P<0.01\right)$ and L1- (57 \pm 3 cells $\left./ \mathrm{mm}^{2} ; P<0.01\right)$ mRNA-expressing RGCs compared with the untreated control group. SC-1 and TAG-1 mRNAs were not detected under S-PBN treatment (Fig. 2b).

The NOS inhibitor I-NAME mimicks the effects of S$P B N$. Systemic treatment with I-NAME after ON transection also significantly reduced the number of RGCs expressing the mRNAs of GAP-43 (99 \pm 6 cells / $\left.\mathrm{mm}^{2} ; P<0.01\right)$ and L1 $\left(86 \pm 4\right.$ cells $\left./ \mathrm{mm}^{2} ; P<0.01\right)$ compared to untreated controls. Very few cells expressed TAG-1 mRNA $\left(2 \pm 0\right.$ cells $\left./ \mathrm{mm}^{2}\right)$, whereas SC-1 mRNA expression was not detected (Fig. 2b).

\section{Effects of BDNF and S-PBN on the Number of GAP-43-, L1-, TAG-1-, and SC-1-mRNA- Expressing RGCs in Grafted Retinae}

BDNF increases the number of GAP-43- and L1-expressing RGCs in grafted retinae. Under BDNF treatment, the number of GAP-43-mRNA-expressing RGCs in grafted retinae significantly increased (178 \pm 10 cells/ $\left.\mathrm{mm}^{2} ; P<0.01\right)$ compared to the grafted control group with vehicle treatment $\left(47 \pm 17\right.$ cells $/ \mathrm{mm}^{2}$ ) (Figs. 3a, $3 \mathrm{~b}$, and 4). All GAP-43-mRNA-expressing cells also exhibited L1 mRNA expression (Fig. 3d). This is demonstrated by the presence of double labeled cells with Fast Red staining indicative of GAP-43 mRNA and BM-purple indicative of L1 mRNA expression (see Methods). However, TAG-1 mRNA was not detected in RGCs of grafted retinae, neither in the vehicleinjected control group nor in the verum-treated group. This is shown in Fig. 3c by the presence of Fast Redlabeled RGCs (GAP-43 mRNA) and by the absence of BM-purple labeled cells (TAG-1 mRNA). The same was true for SC-1 mRNA which could not be detected at all (data not shown). The absence of TAG-1 in situ hybridization signals from RGCs in grafted retinae contrasts to RGCs in axotomized, nongrafted retinae at 21 days after surgery, in which BDNF had led to an elevation of TAG-1 mRNA expression in a subset of RGCs (93 \pm 4 cells $/ \mathrm{mm}^{2}$ ) (Fig. 5). S-PBN in combination with BDNF again counteracted the BDNF effect on mRNA expression. The number of GAP-43 and L1 mRNA expressing RGCs fell to control levels $(71 \pm 10$ 

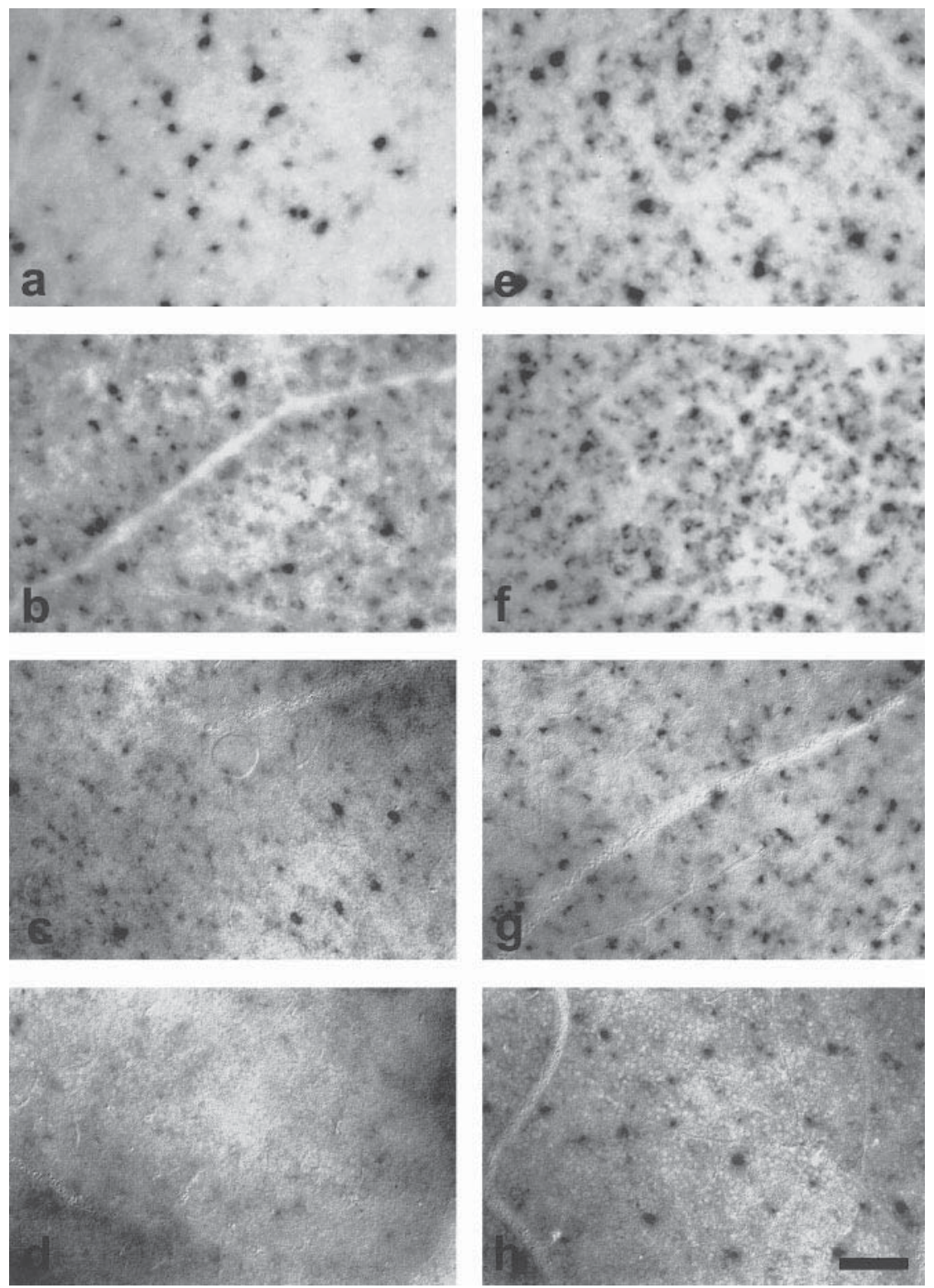

FIG. 1. BDNF upregulates the expression of GAP-43, L1, and TAG-1 mRNAs in RGCs 14 days after ON transection. Representative photographs of flat-mounted retinae at corresponding areas showing the expression of GAP-43 (a), L1 (b), and SC-1 (c) mRNAs in RGCs as detected by in situ hybridization. No signal was observed for TAG-1 mRNA (d). Intraocular injections of BDNF led to an increase in the number of RGCs expressing GAP-43 (e) and L1 (f) and to the detection of TAG-1 mRNA (h). The number of RGCs expressing SC-1 mRNA did not change (g). Bar, $60 \mu \mathrm{m}$.

cells $/ \mathrm{mm}^{2}$ ) (Fig. 4). TAG-1 and SC-1 mRNAs were not detected.

$B D N F$ does not increase the number of RGCs regenerating an axon into the PN graft. Since BDNF had profound effects on the expression of growth-associated genes, we investigated whether BDNF would improve axon regeneration of RGCs into the PN transplant. Within 21 days, $43 \pm 12 \mathrm{RGCs} / \mathrm{mm}^{2}$ had elongated their axons into the transplant in the untreated control group. Intraocular BDNF injections did not result in a significant increase in the number of axon-regenerating RGCs $\left(47 \pm 4\right.$ cells $\left./ \mathrm{mm}^{2}\right)$. Likewise, systemic administration of the free radical scavenger S-PBN did not affect RGC regeneration $\left(42 \pm 3\right.$ cells $\left./ \mathrm{mm}^{2}\right)$. Table 2 shows the retinal distribution of RGCs having regenerated an axon into a PN transplant without any 


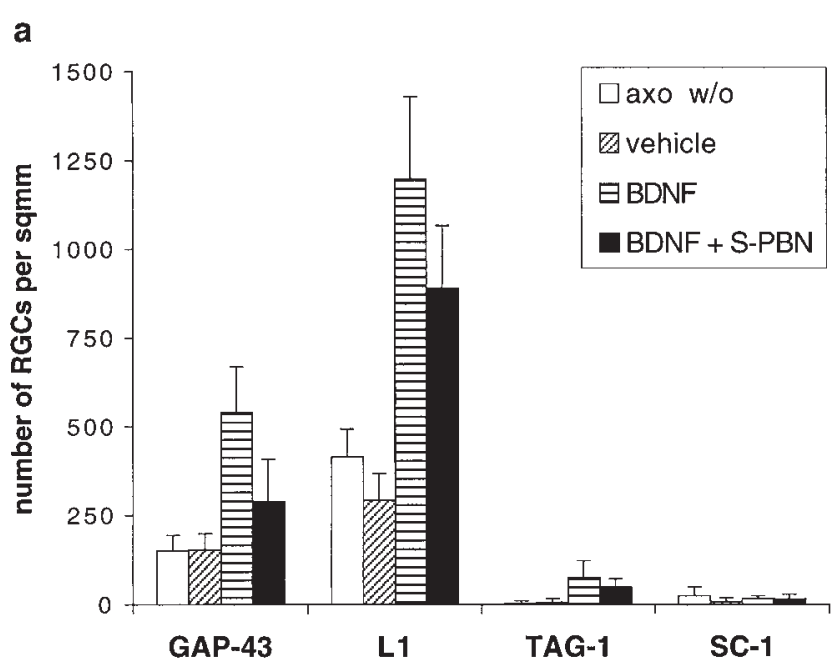

b

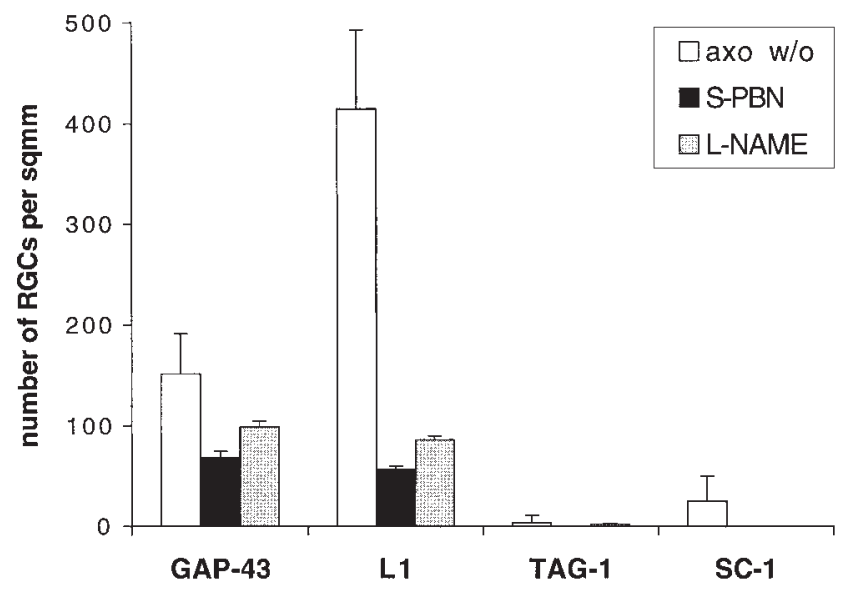

FIG. 2. (a) The effect of BDNF on the mRNA expression of GAP43, L1, and TAG-1 in axotomized RGCs is reduced by S-PBN. Quantification of RGCs expressing the respective mRNAs 14 days after $\mathrm{ON}$ transection without treatment (axo w/o) and treated with intraocular injections of vehicle or BDNF or with combined administration of BDNF and S-PBN. (b) Both S-PBN and I-NAME downregulate the expression of GAP-43, L1, TAG-1, and SC-1. Quantification of RGCs expressing the respective mRNAs 14 days after ON transection without treatment (axo w/o) and with systemic S-PBN or I-NAME treatment. Data are given as mean RGC densities \pm SD ( $n=4$ for each experimental group).

additional treatment and after vehicle, BDNF, and S-PBN treatment.

\section{DISCUSSION}

Besides its known survival promoting activity, BDNF positively influences the transcription of the growth-associated genes GAP-43, L1, and TAG-1 in lesioned RGCs. This is shown here by an increase in the number of GAP-43- and L1-mRNA-expressing RGCs and by the appearance of TAG-1 mRNA in RGCs which in the absence of BDNF do not exhibit any detectable TAG-1 in situ hybridization signal. While the BDNF-mediated effect on mRNA synthesis might enlarge the population of RGCs with an intrinsic competence for axon elongation, it is, however, not sufficient for successful axon regeneration into the PN graft. The number of axon-regenerating RGCs remained unchanged independent of BDNF or vehicle treatment. Simultaneous administration of the free radical scavenger S-PBN or the NOS-inhibitor I-NAME, which on the one hand both improve BDNF neuroprotection of axotomized RGCs, reduce on the other hand the expression of the examined growthassociated genes suggesting a role for NOS activity in the BDNF effect on gene transcription. From these results we conclude that RGC survival and regeneration of RGC axons are two distinct conditions which can be regulated independently.

BDNF treatment led to a threefold increase in RGCs expressing GAP-43 and L1 mRNAs. This increase in cell number could either reflect the survival-promoting action of BDNF or an influence on gene transcription. In the first case, the number of RGCs expressing GAP-43 and L1 should represent a fixed percentage of all surviving RGCs which would be held constant by some other parameter, independent of the factor leading to cell survival. We found only a small increase in the percentage of GAP-43 mRNA expressing RGCs from 42 to $57 \%$, which cannot clarify this question unequivocally because lacking statistical significance. However, the BDNF induced upregulation of TAG-1 mRNA which is not detectable in axotomized but otherwise untreated or vehicle-treated RGCs, and the observation that the absolute number of RGCs expressing SC-1 mRNA remained constant under BDNF treatment favor the idea that BDNF acts as a regulator of gene transcription in RGCs. In addition, the finding by Fournier and co-workers that BDNF can upregulate GAP-43 transcription in axotomized RGCs on the single-cell level employing radioactively labeled in situ probes (Fournier et al., 1997) argues against a mere survival-promoting action of BDNF.

GAP-43 is probably the best characterized growthassociated gene (Skene, 1989; Benowitz and Routtenberg, 1997). Graft regeneration experiments and studies on GAP-43-overexpressing mice strongly suggest that GAP-43 lowers the threshold for nerve sprouting and potentiates its vigor (Aigner et al., 1995; Caroni, 
TABLE 1

Effects of BDNF on RGC Survival 14 Days after Optic Nerve Transection in the Adult Rat

\begin{tabular}{lcccc}
\hline & One-sixth retinal radius & Three-sixths retinal radius & Five-sixths retinal radius & Average \\
\hline Axotomy only & $403 \pm 33$ & $394 \pm 86$ & $292 \pm 101$ & $363 \pm 43 \quad(n=3)$ \\
Vehicle & $553 \pm 94$ & $321 \pm 74$ & $185 \pm 45$ & $353 \pm 70(n=3)$ \\
BDNF 500 & $1307 \pm 104$ & $1002 \pm 30$ & $507 \pm 44$ & $939 \pm 43^{*}(n=4)$ \\
BDNF 500 + S-PBN 100 & $1988 \pm 175$ & $1624 \pm 167$ & $868 \pm 74$ & $1493 \pm 123^{*}(n=9)$ \\
\hline
\end{tabular}

Note. Data are given as mean RGC densities $\left(\right.$ cells $\left./ \mathrm{mm}^{2}\right) \pm \mathrm{SEM}$ at one-sixth, one-half, and five-sixths of the retinal radius and averaged over the radius. BDNF 500, intraocular injections of BDNF at a dose of $500 \mathrm{ng} /$ injection on days 4, 7, and 10 after axotomy. Systemic administration of the free radical scavenger S-PBN $(100 \mathrm{mg} / \mathrm{ml})$ potentiates BDNF mediated neuroprotection (Klöcker et al., 1998). For statistical analysis, one-way ANOVA with Duncan's post hoc test was used ( ${ }^{*} P<0.05$ compared to axotomy alone).

1997). Our results support this hypothesis. The increase in GAP-43-expressing RGCs upon BDNF application correlates well with the BDNF induced increase in intraretinal axonal branch length of RGCs as documented by Sawai et al. (1996). However, GAP-43 is apparently not sufficient for long distance axon elongation (Doster et al., 1991; Strittmatter et al., 1995; Vaudano et al., 1995). GAP-43 expression in axotomized RGCs occurs in the absence of a PN graft and thus in the absence of effective axonal regeneration. Moreover, while BDNF increased the number of
RGCs-expressing GAP-43 and L1, it did not increase the number of RGCs growing an axon into the graft. This observation is in good agreement with an earlier study by Mansour-Robaey and co-workers (1994), who studied axon regeneration of RGCs 6 weeks after PN grafting and a single high-dose injection of BDNF. However, these authors performed a second axotomy to label axon-regenerating RGCs which could have affected cell survival. Yet, by using prelabeled PN grafts, which made a second lesion of regenerating RGC axons unnecessary, we also found no rise in the
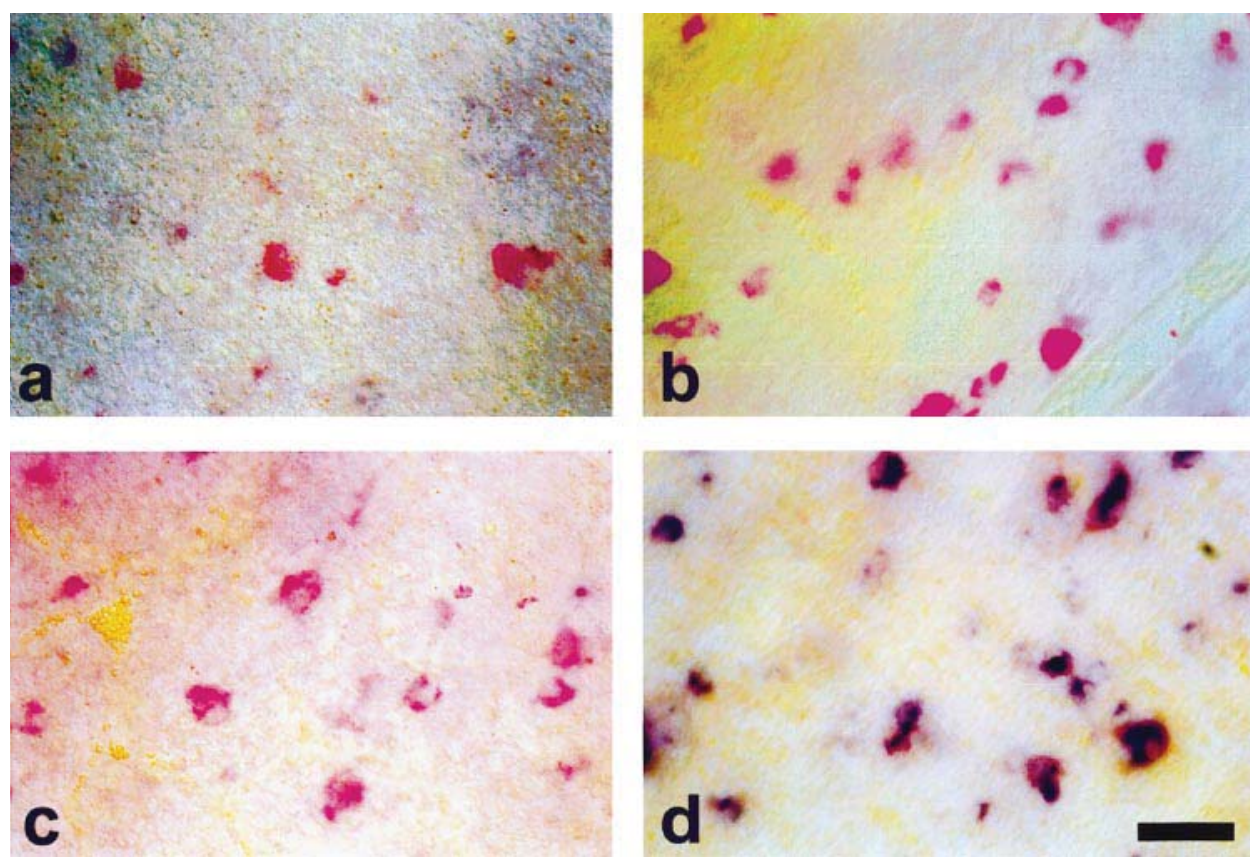

FIG. 3. BDNF upregulates the expression of GAP-43 and L1 mRNAs in RGCs 21 days after PN grafting. Representative photographs of flat-mounted retinae at corresponding areas showing the expression of GAP-43 mRNA after vehicle treatment (a) and BDNF treatment (b) as detected by in situ hybridization. GAP-43 mRNA expression (Fast Red) colocalized with L1 mRNA expression (BM-purple) (d), but neither with TAG-1 (BM-purple) (c) nor with SC-1 mRNA expression (data not shown). Bar, $30 \mu \mathrm{m}$. 


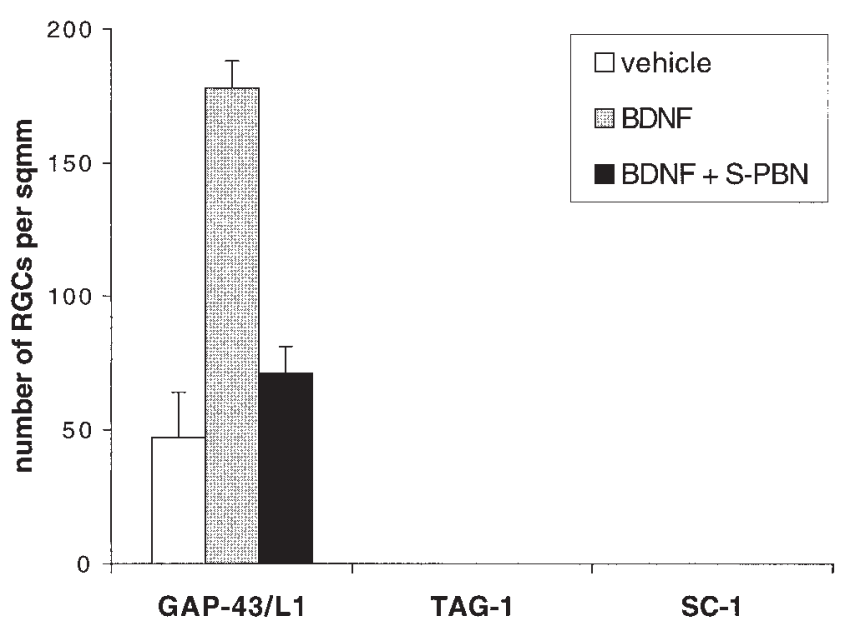

FIG. 4. Quantification of RGCs expressing GAP-43, L1, TAG-1, and SC-1 mRNAs 21 days after PN grafting treated with vehicle, BDNF, or with a combination of BDNF and S-PBN. BDNF led to a threefold increase in the number of GAP-43 and L1 mRNAexpressing RGCs, whereas simultaneous administration of S-PBN attenuated this effect to control levels. TAG-1 and SC-1 mRNA expression was not observed independent of the treatment. Data are given as mean RGC densities \pm SD $(n=4$ for each experimental group).

number of axon regenerating RGCs in BDNF treated versus untreated animals. This leaves the question open which parameters account for axon regeneration in the few RGCs that do it.

L1 is a cell adhesion molecule of the IgSF whose expression in the CNS is restricted to postmitotic neurons and temporally correlated with neuronal maturation, migration and neurite extension (Daniloff et al., 1986; Linnemann et al., 1988). In our previous study, we found that L1 mRNA expression persists in a subpopulation of RGCs also in the adult rat retina (Jung et al., 1997). Fourteen days after ON transection the absolute number of L1-expressing RGCs had declined and was now identical with the population of surviving RGCs. Here we show that all RGCs which are protected by BDNF after axotomy contained L1 mRNA. This suggests that L1 may be a survival marker of axotomized RGCs. However, the free radical scavenger S-PBN, as discussed below, downregulated its expression while at the same time BDNFmediated cell survival is increased (Klöcker et al., 1998).

As for L1, the expression of the axonal glycoprotein TAG-1 reaches a maximum during neurite outgrowth in early development (Yamamoto et al., 1986; Dodd and Jessell, 1988; Furley et al., 1990). In rat RGCs, its expression persists into adulthood but is downregulated directly after axonal lesion (Jung et al., 1997). It has been suggested that CNS neurons, in contrast to the PNS, are not capable of reexpressing TAG-1 (Karagogeos et al., 1991). Our results show that BDNF treatment can upregulate TAG-1 mRNA expression in lesioned CNS neurons in vivo. TAG-1 protein is attached to the axonal membrane via a glycosyl phosphatidylinositol linkage and can be released into the extracellular space. It can there function as a substrate adhesion molecule interacting either homophilically or heterophilically with L1 (Felsenfeld et al., 1994; Malhotra et al., 1998). Thus, RGCs which upregulate TAG-1 after BDNF treatment might get engaged in a broader range of interactions which in turn may improve the conditions for axon regeneration. Surprisingly, however, the BDNF effect on TAG-1 mRNA expression was not observed when RGCs were offered a PN graft. One could speculate that some factor originating from within the PN graft downregulates TAG-1 expression and makes it dispensible. Alternatively, the downregulation of TAG-1 expression in grafted retinae occurs in exchange with upregulation of another CAM as a mechanism by which RGCs adapt to a changing environment, from CNS tissue within the retina to PNS tissue in the graft. Commissural axons in the developing spinal cord, for instance, switch from TAG-1 to L1 expression as they cross the floor plate (Dodd and Jessell, 1988).

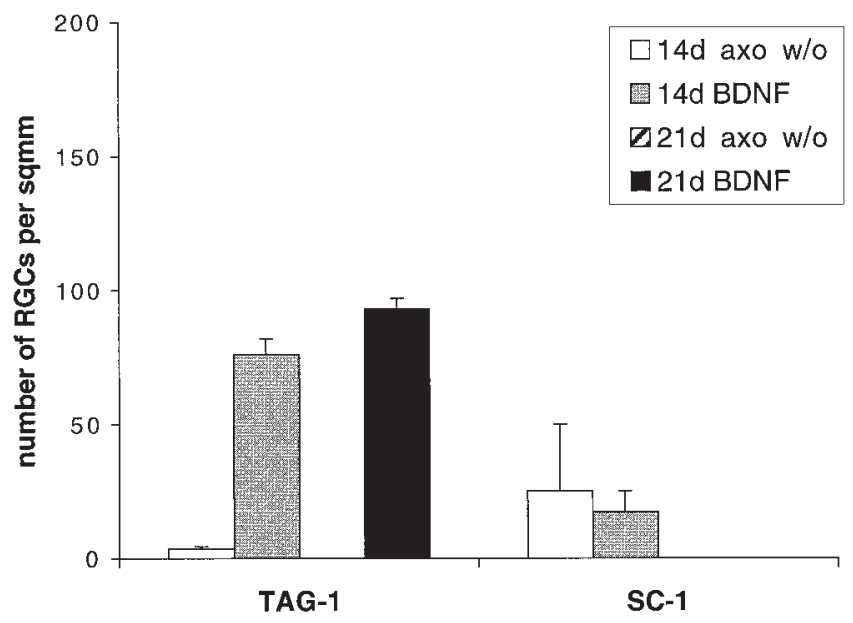

FIG. 5. Upregulation of TAG-1 mRNA expression by BDNF persists up to 21 days after ON transection. Quantification of RGCs expressing TAG-1 and SC-1 mRNAs without treatment (axo w/o) or with BDNF treatment 14 and 21 days after axotomy. Data are given as mean RGC densities \pm SD $(n=4$ for each experimental group). 
TABLE 2

BDNF Does Not Improve Long-Distance Axon Regeneration of Axotomized RGC 21 Days after PN Grafting

\begin{tabular}{lccrr}
\hline & One-sixths retinal radius & Three-sixths retinal radius & Five-sixths retinal radius & Average \\
\hline Graft only & $56 \pm 15$ & $40 \pm 6$ & $33 \pm 8$ & $43 \pm 9(n=3)$ \\
Vehicle & $59 \pm 7$ & $42 \pm 5$ & $25 \pm 3$ & $42 \pm 4(n=3)$ \\
BDNF 500 & $56 \pm 1$ & $47 \pm 3$ & $39 \pm 7$ & $47 \pm 3(n=4)$ \\
S-PBN 100 & $57 \pm 5$ & $40 \pm 3$ & $30 \pm 4$ & $42 \pm 3(n=3)$ \\
\hline
\end{tabular}

Note. Data are given as mean densities (cells $/ \mathrm{mm}^{2}$ ) \pm SEM of retrogradely labeled RGCs at one-sixth, one-half, and five-sixths of the retinal radius and averaged over the radius. BDNF 500, intraocular injections of BDNF at a dose of $500 \mathrm{ng} / \mathrm{injection}$ on days 4, 8, 12, and 16 after axotomy and grafting. S-PBN 100, systemic administration of S-PBN $(100 \mathrm{mg} / \mathrm{ml})$ twice daily.

Systemic application of the free radical scavenger S-PBN potentiated BDNF-mediated neuroprotection on axotomized RGCs in our previous study (Klöcker et al., 1998). Intriguingly, this combined treatment did not enlarge but diminished the number of RGCs expressing GAP-43 and L1. Moreover, TAG-1 and SC-1 mRNAs could not be detected at all. As a single treatment, S-PBN does not affect cell survival at all (Klöcker et al., 1998), but suppressed GAP-43 and L1 expression when compared to the axotomized but otherwise untreated controls. Nitrone-based spin trap molecules such as S-PBN have proved to be neuroprotective in animal models of excitotoxic CNS lesions (Schulz and Beal, 1995; Schulz et al., 1995; Kuroda et al., 1996). Their precise mode of action has not yet been elucidated. Growing evidence suggests that, in addition to scavenging free radicals, nitrones can regulate gene transcription (Hensley et al., 1997). However, since the specific NOS inhibitor I-NAME mimicked the suppressive effects of S-PBN, we assume that SPBN does not directly reduce the expression of the examined mRNAs, but that a reduction of free $\mathrm{NO}$ in the retina achieved by S-PBN or I-NAME might account for this effect. Our previous study has shown that both $\mathrm{ON}$ transection alone and to an even greater extent additional intraocular injection of BDNF increase retinal NOS activity (Klöcker et al., 1999). In the present study, we demonstrate that NOS inhibition downregulates growth-associated gene transcription in axotomized but otherwise untreated or BDNFtreated RGCs. This offers the hypothesis that NO could mediate the effects of axotomy and BDNF on gene transcription in RGCs. Such view is consistent with studies that implicate NO in the transcriptional control of immediate early gene expression in various cell types (Nathan and Xie, 1994).

It is noteworthy that $\mathrm{NO}$ can activate two major pathways of BDNF signal transduction, the phosphatidylinositol-3'-kinase (PI-3-K)/protein kinase B
(PKB) and the Ras/mitogen-activated protein kinase (MAPK) pathway, the latter leading eventually to gene transcription (Lander et al., 1995; Deora et al., 1998). Thus, BDNF might amplify its signaling in a feed forward loop by increasing retinal NOS activity. Though we cannot completely exclude that the reduction in the number of mRNA-expressing RGCs under S-PBN or I-NAME treatment simply adds to the effects of ON transection or BDNF treatment, it is tempting to speculate that these agents functionally antagonize gene expression elicited by axonal lesion or BDNF treatment via inhibiting the synthesis of NO.

Our results do not only suggest a molecular mechanism underlying BDNF-induced transcriptional regulation of growth-associated genes, but also demonstrate that in lesioned CNS neurons, survival and their competence to regenerate an axon are two distinct conditions. The reduction of NOS activity significantly potentiates BDNF-mediated survival of axotomized RGCs (Klöcker et al., 1998, 1999), but at the same time it downregulates the transcription of growth-associated genes as shown in the present study. This has profound consequences for the development of pharmacological treatment strategies in CNS lesions. Although preventing secondary neuronal cell loss is doubtless a prerequisite for promoting axonal regeneration, our data demonstrate that these two therapeutic goals are not equivalent. Dissection of the signal transduction pathways which lead to either response will be necessary to design combinatory treatment regimens that promote neuronal survival and stimulate axon regrowth at the same time.

\section{ACKNOWLEDGMENTS}

The authors thank S. Thomsen and M. Wiechers for excellent technical assistance. This work was supported by the Bundesministerium für Bildung und Forschung (BMBF). 


\section{REFERENCES}

Aguayo, A. J., Rasminsky, M., Bray, G. M., Carbonetto, S., McKerracher, L., Villegas Perez, M. P., Vidal Sanz, M., \& Carter, D. A. (1991) Degenerative and regenerative responses of injured neurons in the central nervous system of adult mammals. Phil. Trans. R. Soc. Lond. B. Biol. Sci. 331, 337-343.

Aigner, L., Arber, S., Kapfhammer, J. P., Laux, T., Schneider, C., Botteri, F., Brenner, H. R., \& Caroni, P. (1995) Overexpression of the neural growth-associated protein GAP-43 induces nerve sprouting in the adult nervous system of transgenic mice. Cell $\mathbf{8 3}$, 269-278.

Barbacid, M. (1994) The Trk family of neurotrophin receptors. J. Neurobiol. 25, 1386-1403.

Barde, Y. A., Edgar, D., \& Thoenen, H. (1982) Purification of a new neurotrophic factor from mammalian brain. EMBO J. 1, 549-553.

Benowitz, L. I., \& Routtenberg, A. (1997) GAP-43: An intrinsic determinant of neuronal development and plasticity. Trends Neurosci. 20, 84-91.

Bock, E., Richter-Landsberg, C., Faissner, A., \& Schachner, M. (1985) Demonstration of immunocytochemical identity between the nerve growth factor-inducible large external (NILE) glycoprotein and the cell adhesion molecule L1. EMBO J. 4, 2765-2768.

Bovolenta, P., Wandosell, F., \& Nieto Sampedro, M. (1993) Characterization of a neurite outgrowth inhibitor expressed after CNS injury. Eur. J. Neurosci. 5, 454-465.

Breitschopf, H., Suchanek, G., Gould, R. M., Colman, D. R., \& Lassmann, H. (1992) In situ hybridization with digoxigenin-labeled probes: sensitive and reliable detection method applied to myelinating rat brain. Acta Neuropathol. Berlin. 84, 581-587.

Brittis, P. A., \& Silver, J. (1995) Multiple factors govern intraretinal axon guidance: A time-lapse study. Mol. Cell. Neurosci. 6(5), 413432.

Caroni, P. (1997) Intrinsic neuronal determinants that promote axonal sprouting and elongation. BioEssays 19,767-775.

Caroni, P., \& Schwab, M. E. (1988) Antibody against myelin-associated inhibitor of neurite growth neutralizes nonpermissive substrate properties of CNS white matter. Neuron 1, 85-96.

Cellerino, A., \& Kohler, K. (1997). Brain-derived neurotrophic factor/neurotrophin-4 receptor TrkB is localized on ganglion cells and dopaminergic amacrine cells in the vertebrate retina. J. Comp. Neurol. 386, 149-160.

Cui, Q., \& Harvey, A. R. (1995) At least two mechanisms are involved in the death of retinal ganglion cells following target ablation in neonatal rats. J. Neurosci. 15, 8143-8155.

Daniloff, J. K., Chuong, C. M., Levi, G., \& Edelman, G. M. (1986) Differential distribution of cell adhesion molecules during histogenesis of the chick nervous system. J. Neurosci. 6, 739-758.

David, S., \& Aguayo, A. J. (1985) Axonal regeneration after crush injury of rat central nervous system fibres innervating peripheral nerve grafts. J. Neurocytol. 14, 1-12.

Deora, A. A., Win, T., Vanhaesebroeck, B., \& Lander, H. M. (1998) A redox-triggered ras-effector interaction: Recruitment of phosphatidylinositol 3'-kinase to Ras by redox stress. J. Biol. Chem. 273, 29923-29928.

Dodd, J., \& Jessell, T. M. (1988) Axon guidance and the patterning of neuronal projections in vertebrates. Science 242, 692-699.

Doster, S. K., Lozano, A. M., Aguayo, A. J., \& Willard, M. B. (1991) Expression of the growth-associated protein GAP-43 in adult rat retinal ganglion cells following axon injury. Neuron 6, 635-647.

Felsenfeld, D. P., Hynes, M. A., Skoler, K. M., Furley, A. J., \& Jesell, T. M. (1994) TAG-1 can mediate homophilic binding, but neurite outgrowth on TAG-1 requires an L1-like molecule and beta 1 integrins. Neuron 12, 675-690.

Fournier, A. E., Beer, J., Arregui, C. O., Essagian, C., Aguayo, A. J., \& McKerracher, L. (1997) Brain-derived neurotrophic factor modulates GAP-43 but not $\mathrm{T}$ alpha1 expression in injured retinal ganglion cells of adult rats. J. Neurosci. Res. 47, 561-572.

Furley, A. J., Morton, S. B., Manalo, D., Karagogeos, D., Dodd, J., \& Jessell, T. M. (1990) The axonal glycoprotein TAG-1 is an immunoglobulin superfamily member with neurite outgrowth-promoting activity. Cell 61, 157-170.

Garcia-Valenzuela, E., Gorczyca, W., Darzynkiewicz, Z., \& Sharma, S. C. (1994) Apoptosis in adult retinal ganglion cells after axotomy. J. Neurobiol. 25(4), 431-438.

Hensley, K., Carney, J. M., Stewart, C. A., Tabatabaie, T., Pye, Q., \& Floy, R. A. (1997) Nitrone-based free radical traps as neuroprotective agents in cerebral ischaemia and other pathologies. Int. Rev. Neurobiol. 40, 299-317.

Herdegen, T., Skene, P., \& Bähr, M. (1997) The c-Jun transcription factor-Bipotential mediator of neuronal death, survival and regeneration. Trends Neurosci. 20, 227-231.

Hirsch, S., \& Bähr, M. (1999) Immunocytochemical characterization of reactive optic nerve astrocytes and meningeal cells. Glia 26, $36-46$.

Jelsma, T. N., Friedman, H. H., Berkelaar, M., Bray, G. M., \& Aguayo, A. J. (1993) Different forms of the neurotrophin receptor trkB mRNA predominate in rat retina and optic nerve. J. Neurobiol. 24, 1207-1214.

Jo, S. A., Wang, E., \& Benowitz, L. I. (1999) Ciliary neurotrophic factor is an axogenesis factor for retinal ganglion cells. Neuroscience 89, 579-591.

Johnson, J. E., Barde, Y. A., Schwab, M., \& Thoenen, H. (1986) Brain-derived neurotrophic factor supports the survival of cultured rat retinal ganglion cells. J. Neurosci. 6, 3031-3038.

Jung, M., Petrausch, B., \& Stuermer, C. A. (1997) Axon-regenerating retinal ganglion cells in adult rats synthesize the cell adhesion molecule L1 but not TAG-1 or SC-1. Mol. Cell. Neurosci. 9, 116-131.

Kapfhammer, J. P., Christ, F., \& Schwab, M. E. (1994) The expression of GAP-43 and synaptophysin in the developing rat retina. Brain. Res. Dev. Brain. Res. 80, 251-260.

Karagogeos, D., Morton, S. B., Casano, F., Dodd, J., \& Jessell, T. M. (1991) Developmental expression of the axonal glycoprotein TAG-1: Differential regulation by central and peripheral neurons in vitro. Development 112, 51-67.

Klöcker, N., Cellerino, A., \& Bähr, M. (1998) Free radical scavenging and inhibition of nitric oxide synthase potentiates the neurotrophic effects of brain-derived neurotrophic factor on axotomized retinal ganglion cells in vivo. J. Neurosci. 18, 1038-1046.

Klöcker, N., Kermer, P., Gleichmann, M., Weller, M., \& Bähr, M. (1999) Both the neuronal and inducible isoform contribute to upregulation of retinal nitric oxide synthase activity by brainderived neurotrophic factor. J. Neurosci. 19, 8517-8527.

Kuroda, S., Katsura, K., Hillered, L., Bates, T. E., \& Siesjo, B. K. (1996) Delayed treatment with alpha-phenyl-N-tert-butyl nitrone (PBN) attenuates secondary mitochondrial dysfunction after transient focal cerebral ischemia in the rat. Neurobiol. Dis. 3, 149-157.

Lander, H. M., Ogiste, J. S., Pearce, S. F., Levi, R., \& Novogrodsky, A. (1995) Nitric oxide-stimulated guanine nucleotide exchange on p21ras. J. Biol. Chem. 270, 7017-7020.

Lang, D. M., Lommel, S., Jung, M., Ankerhold, R., Petrausch, B., Laessing, U., Wiechers, M. F., Plattner, H., \& Stuermer, C. A. (1998) Identification of reggie-1 and reggie-2 as plasmamembrane-associated proteins which cocluster with activated GPI- 
anchored cell adhesion molecules in non-caveolar micropatches in neurons. J. Neurobiol. 37, 502-523.

Leibrock, J., Lottspeich, F., Hohn, A., Hofer, M., Hengerer, B., Masiakowski, P., Thoenen, H., \& Barde, Y. A. (1989) Molecular cloning and expression of brain-derived neurotrophic factor. $\mathrm{Na}$ ture 341, 149-152.

Lewin, G. R., \& Barde, Y. A. (1996) Physiology of the neurotrophins. Annu. Rev. Neurosci. 19, 289-317.

Lindsay, R. M., Wiegand, S. J., Altar, C. A., \& DiStefano, P. S. (1994) Neurotrophic factors: from molecule to man. Trends Neurosci. 17, 182-190.

Linnemann, D., Edvardsen, K., \& Bock, E. (1988) Developmental study of the cell adhesion molecule L1. Dev. Neurosci. 10, 34-42.

Malhotra, J. D., Tsiotra, P., Karagogeos, D., \& Hortsch, M. (1998) Cis-activation of L1-mediated ankyrin recruitment by TAG-1 homophilic cell adhesion. J. Biol. Chem. 273, 33354-33359.

Mansour-Robaey, S., Clarke, D. B., Wang, Y. C., Bray, G. M., \& Aguayo, A. J. (1994) Effects of ocular injury and administration of brainderived neurotrophic factor on survival and regrowth of axotomized retinal ganglion cells. Proc. Natl. Acad. Sci. USA 91, 1632-1636.

McKerracher, L., David, S., Jackson, D. L., Kottis, V., Dunn, R. J., \& Braun, P. E. (1994) Identification of myelin-associated glycoprotein as a major myelin-derived inhibitor of neurite growth. Neuron 13, 805-811.

Mey, J., \& Thanos, S. (1993) Intravitreal injections of neurotrophic factors support the survival of axotomized retinal ganglion cells in adult rats in vivo. Brain Res. 602, 304-317.

Meyer, R. L., Miotke, J. A., \& Benowitz, L. I. (1994) Injury induced expression of growth-associated protein- 43 in adult mouse retinal ganglion cells in vitro. Neuroscience 63(2), 591-602.

Meyer-Franke, A., Kaplan, M., Pfrieger, F. W., \& Barres, B. A. (1995) Characterization of the signaling interactions that promote the survival and growth of developing retinal ganglion cells. Neuron 15, 805-819.

Nathan, C., \& Xie, Q. W. (1994) Regulation and biosynthesis of nitric oxide. J. Biol. Chem. 269, 13725-13728.

Peinado Ramon, P., Salvador, M., Villegas Perez, M. P., \& Vidal Sanz, M. (1996) Effects of axotomy and intraocular administration of NT-4, NT-3, and brain-derived neurotrophic factor on the survival of adult rat retinal ganglion cells: A quantitative in vivo study. Invest. Ophthalmol. Vis. Sci. 37, 489-500.

Prince, J. T., Nishiyama, A., Healy, P. A., Beasley, L., \& Stallcup, W. B. (1992) Expression of the F84.1 glycoprotein in the spinal cord and cranial nerves of the developing rat. Dev. Brain Res. 68, 193-201.

Ramon y Cajal, S. (1928/1991) Degeneration and Regeneration of the Nervous System. Hafner, New York.

Reh, T. A., Tetzlaff, W., Ertlmaier, A., \& Zwiers, H. (1993) Developmental study of the expression of B50/GAP-43 in rat retina. J. Neurobiol. 24(7), 949-958.

Rickman, D. W., \& Brecha, N. C. (1995) Expression of the protooncogene, trk, receptors in the developing rat retina. Vis. Neurosci. 12, 215-222.

Sauve, Y., Sawai, H., \& Rasminsky, M. (1995) Functional synaptic connections made by regenerated retinal ganglion cell axons in the superior colliculus of adult hamsters. J. Neurosci. 15, 665-675.

Sawai, H., Clarke, D. B., Kittlerova, P., Bray, G. M., \& Aguayo, A. J. (1996) Brain-derived neurotrophic factor and neurotrophin-4/5 stimulate growth of axonal branches from regenerating retinal ganglion cells. J. Neurosci. 16, 3887-3894.

Schachner, M. (1994) Neural recognition molecules in disease and regeneration. Curr. Opin. Neurobiol. 4, 726-734.

Schaden, H., Stuermer, C. A., \& Bähr, M. (1994) GAP-43 immunoreactivity and axon regeneration in retinal ganglion cells of the rat. J. Neurobiol. 25, 1570-1578.

Schulz, J. B., \& Beal, M. F. (1995) Neuroprotective effects of free radical scavengers and energy repletion in animal models of neurodegenerative disease. Ann. N. Y. Acad. Sci. 765, 100-110.

Schulz, J. B., Henshaw, D. R., Siwek, D., Jenkins, B. G., Ferrante, R. J., Cipolloni, P. B., Kowall, N. W., Rosen, B. R., \& Beal, M. F. (1995) Involvement of free radicals in excitotoxicity in vivo. J. Neurochem. 64, 2239-2247.

Schwab, M. E., Kapfhammer, J. P., \& Bandtlow, C. E. (1993) Inhibitors of neurite growth. Annu. Rev. Neurosci. 16, 565-595.

Skene, J. H. P. (1989) Axonal growth-associated proteins. Annu. Rev. Neurosci. 12, 127-156.

Strittmatter, S. M., Fankhauser, C., Huang, P. L., Mashimo, H., \& Fishman, M. C. (1995) Neuronal pathfinding is abnormal in mice lacking the neuronal growth cone protein GAP-43. Cell 80, 445452.

Tetzlaff, W., Alexander, S. W., Miller, F. D., \& Bisby, M. A. (1991) Response of facial and rubrospinal neurons to axotomy: Changes in mRNA expression for cytoskeletal proteins and GAP-43. J. Neurosci. 11, 2528-2544.

Tetzlaff, W., Kobayashi, N. R., Giehl, K. M., Tsui, B. J., Cassar, S. L., \& Bedard, A. M. (1994) Response of rubrospinal and corticospinal neurons to injury and neurotrophins. Prog. Brain Res. 103, 271286.

Thanos, S., Bähr, M., Barde, Y. A., \& Vanselow, J. (1989) Survival and axonal elongation of adult rat retinal ganglion cells: in vitro effects of lesioned sciatic nerve and brain-derived neurotrophic factor (BDNF). Eur. J. Neurosci. 1, 19-26.

Vaudano, E., Campbell, G., Anderson, P. N., Davies, A. P., Woolhead, C., Schreyer, D. J., \& Lieberman, A. R. (1995) The effects of a lesion or a peripheral nerve graft on GAP-43 upregulation in the adult rat brain: An in situ hybridization and immunocytochemical study. J. Neurosci. 15, 3594-3611.

Villegas Perez, M. P., Vidal Sanz, M., Bray, G. M., \& Aguayo, A. J. (1988) Influences of peripheral nerve grafts on the survival and regrowth of axotomized retinal ganglion cells in adult rats. J. Neurosci. 8, 265-80.

Villegas Perez, M. P., Vidal Sanz, M., Rasminsky, M., Bray, G. M., \& Aguayo, A. J. (1993) Rapid and protracted phases of retinal ganglion cell loss follow axotomy in the optic nerve of adult rats. J. Neurobiol. 24, 23-36.

Westerfield, M. (1994) The Zebrafish Book: A Guide for the Laboratory Use of Zebrafish (Brachydanio rerio). Univ. of Oregon Press, Eugene, OR.

Wilkinson, D. G. (1992) In Situ Hybridisation: A Practical Approach. IRL Press at Oxford Univ. Press, Oxford.

Yamamoto, M., Boyer, A. M., Crandall, J. E., Edwards, M., \& Tanake, H. (1986) Distribution of stage-specific neurite-associated proteins in the developing murine nervous system recognized by a monoclonal antibody. J. Neurosci. 6, 3576-3594. 